\title{
Prevalence of Internal Parasitic Helminthes Infected Oreochromis niloticus (Nile Tilapia), Clarias gariepinus (African Catfish) and Cyprinus carpio (Common Carp) in Lake Lugo (Hayke), Northeast Ethiopia
} Amare $A^{*}$, Alemayehu $A$ and Aylate A

School of Veterinary Medicine, Wollo University, P.O. Box 1145, Dessie, Ethiopia

\begin{abstract}
An investigation was conducted from November, 2010 and August, 2011 in Lake Lugo (Hayke), northeast Ethiopia, with the aim of determining the prevalence and identifying the species of internal parasites from freshwater fish. A total of 412 randomly selected fishes comprising of 225 Oreochromis niloticus, 72 Clarias gariepinus and 115 Cyprinus carpio were examined for internal helminthes parasites. An overall prevalence of $47.8 \%(197 / 412)$ internal parasitic infestation was assessed. Statistically significant difference at $p<0.05$ was noted in the prevalence of internal parasites among the different species, length and weight of fish. However, the difference between sexes was not statistically significant at $p>0.05$, but the prevalence was a bit higher in females $(48.31 \%)$ than males (47.44\%). Prevalence of internal parasites was higher in Clarias gariepinus $(91.7 \%)$ followed by Oreochromis niloticus (50.22\%), and Cyprinus carpio (15.6\%) species. Six parasite species: three nematodes (Contracecum spp., Camallanus spp., Eustrongylides spp.); one trematode (Clinostomum spp.) and two cestodes (Ligula intestinalis, Proteocephalus spp.) were identified from the body cavities and gastrointestinal tracts of fishes. In conclusion, the prevalence of internal parasitic infestations was very high and the study determined six parasitic species present in fish, which were not previously examined in this Lake.
\end{abstract}

Keywords: Ethiopia; Fish; Lake Lugo; Internal Parasites; Prevalence

\section{Introduction}

As a landlocked country following the secession of Eritrea in 1993, fisheries in Ethiopia come exclusively from inland sources. In 2008, fish catch was estimated at around 17,000 tons (accounting for about $1.7 \%$ of the regional volumes), the bulk of which $(74 \%)$ originating from the six main lakes (Tana, Ziway, Langano, Hawassa, Abaya and Chamo) and a further $26 \%$ from the other water bodies. The countries fish potential is estimated at 45,000-51,500 tons per year, according to several sources. Thus, less than $38 \%$ of this potential is currently exploited, demonstrating considerable room for further expansion through proper management. The construction of new reservoirs, under-exploited river fisheries and aquaculture are some of the development prospects to this end [1]. Aquaculture is recognized as an alternative means of achieving food security and poverty reduction in the rural area, and is now considered an integral part of rural and agricultural development policies and strategies in Ethiopia. However, much remains to build institutional capacity in the areas of research, technology and training, which will requires external assistance [2].

A hundred local fish species have been identified, while the bulk of the production is made of Tilapia, Lates, Barbus, Bagrus, Clarias and Labeo species. Approximately $80 \%$ of the catch is Tilapia, although Nile perch is caught in large quantities on Lakes Chamo and Abaya, as well as in major riverine fisheries. Most of the remainder of the lake catches consists of catfish and Barbus [1].

Lake Lugo (Hayke) provides a habitat to different fish species, water birds and aquatic organisms. The fish production potential of the Lugo Lake is estimated as 400 ton/year, and the off take rate is $83 \%$ as reported by FDRE (Federal Democratic Republic of Ethiopia) [3].

In both natural environments and in culture, disease has a serious impact on fish. Disease is universally recognized as one of the most serious threats to the commercial success of aquaculture [4]. Parasitic diseases of fish are among these diseases which has great economic and public health importance particularly in the tropics [5]. In many cases, they have proved to be a serious problem causing economic losses in the fishing industry and in aquaculture. In fish farming, parasites may lead to epidemics and mortalities, and as the culture of fish becomes more intensive and widely spread, fish parasites infection will be more liable to become more serious economic and health issues [6].

Knowledge of the parasites of fish has accumulated in many parts of the world especially in Europe, Russia and USA, but such comparative studies in Africa have been lacking until recently. Research commitments to the study of parasites of fresh water and marine fishes of the African continent have been sporadic and inadequate considering the fish wealth of the continent. This has been attributed to the lack of laboratory equipment, skilled man power, lack of public awareness on the fish production and health, library facilities $[7,8]$. Regarding the diseases of fish in general and parasitic diseases in particular, in Ethiopia information is scant and inadequate except for few researches which have not been well documented, hitherto, no any research have been conducted in Lake Lugo (Hayke).

Therefore, the objective of this research was to determine the prevalence of internal parasites and to assess the predisposing factors associated with the occurrence of these parasites in Lugo Lake.

${ }^{*}$ Corresponding author: Amare A,School of Veterinary Medicine, Wollo University, P.O. Box 1145, Dessie, Ethiopia, Tel: 2511338533; E-mail: abadi.amare@yahoo.com

Received March 21, 2014; Accepted May 08, 2014; Published May 15, 2014

Citation: Amare A, Alemayehu A, Aylate A (2014) Prevalence of Internal Parasitic Helminthes Infected Oreochromis niloticus (Nile Tilapia), Clarias gariepinus (African Catfish) and Cyprinus carpio (Common Carp) in Lake Lugo (Hayke), Northeast Ethiopia. J Aquac Res Development 5: 233 doi:10.4172/2155-9546.1000233

Copyright: $\odot 2014$ Amare A, et al. This is an open-access article distributed under the terms of the Creative Commons Attribution License, which permits unrestricted use, distribution, and reproduction in any medium, provided the original author and source are credited. 
Citation: Amare A, Alemayehu A, Aylate A (2014) Prevalence of Internal Parasitic Helminthes Infected Oreochromis niloticus (Nile Tilapia), Clarias gariepinus (African Catfish) and Cyprinus carpio (Common Carp) in Lake Lugo (Hayke), Northeast Ethiopia. J Aquac Res Development 5: 233 doi:10.4172/2155-9546.1000233

Page 2 of 5

\section{Materials and Methods}

\section{Study area}

The study was conducted on one of the high land Lakes of Ethiopia; Lake Lugo (Hayke) which is located in South Wollo Zone, Northeast Ethiopia. It is located $440 \mathrm{~km}$ north of Addis Ababa, situated at $11015^{\prime} \mathrm{N}$ latitude, 39057'E longitudes, and at an altitude of 2030 m.a.s.l. [9]. The study area is categorized as sub-humid tropical with an annual rainfall of $1173 \mathrm{~mm}$ and a mean temperature of $18.2^{\circ} \mathrm{C}$. The major rainy season is from July to September.

Lugo Lake has an area of $23 \mathrm{~km} 2$ and a maximum depth of $88.2 \mathrm{~m}$ and mean depth of $37.37 \mathrm{~m}$ [10]. The Lake has no visible outlet and the water is described as clear and greenish. Lake Lugo (Hayke) provides a habitat to different fish species, water birds and aquatic organisms. It also plays an economical role via tourism and fishery. The fishes that inhabit Lake Lugo are Oreochromis niloticus (Nile Tilapia), Clarias gariepinus (African catfish), and Cyprinus carpio (Common carp) [7].

\section{Study design, sample size determination and study animals}

Cross sectional study design was used to determine and to identify the prevalent parasitic species on randomly selected three species of fish, namely Oreochromis niloticus, Clarias gariepinus and Cyprinus carpio, which were purchased from fishermen around the lake.

The sample size required for this study was determined based on the expected prevalence of internal parasitic infestation and desired absolute precision according to Thrusfield [11]. Since, there was no previous research done in this area, 50\% expected prevalence, $95 \%$ confidence interval and $5 \%$ precision were used to estimate the sample size. Hence, a minimum of 384 fishes were considered in this study.

Sample collection, Sampling and Examination of specimens for Parasites: 412 randomly selected fresh specimens of 225 Oreochromis niloticus, 72 Clarias gariepinus and 115 Cyprinus carpio recovered by local fishermen were purchased and transported to the laboratory in cool boxes for parasitological examination. The total length (standard length) and weight of each fish were measured and recorded following the procedures described by Paperna [5] and specimens were sexed by examination of the anal fin and gonads. The fishes were categorized into four groups based on their weight to determine their age groups. Fish weighing $0.08-0.1 \mathrm{~kg}$ were classified as the fingerlings, $0.11-0.2$ $\mathrm{kg}$ as juvenile, $0.21-0.3 \mathrm{~kg}$ as young and $>0.31 \mathrm{~kg}$ as adult fish [12]. The average length of fish measured $12.26 \mathrm{~cm}$ and average weight was $112.27 \mathrm{gm}$. The maximum and minimum fish lengths measured were $8 \mathrm{~cm}$ and $50 \mathrm{~cm}$ and the maximum and minimum weight were $70 \mathrm{gm}$ and $1800 \mathrm{gm}$, respectively.

According to the methods described by Noga [4] and Marcogliese [13], the fishes were opened dorso-ventrally examined and processed for the presence of internal parasites. The body cavity and visceral surfaces, the gonads, liver, heart and gall bladder were examined for parasites. The viscera and gill filaments were kept on petridishes and bathed with the physiological saline solution ( $0.7 \% \mathrm{Nacl}$ solution) for parasites recovery. The organs such as stomach and intestine were opened for the examination of parasites. All the collected parasites were fixed in glycerine for further identification.

\section{Identification of parasites}

The helminthic parasites were identified morphologically and parasitologically using standard identification keys and pictorial guides [14-18].

\section{Data analysis}

Data were analyzed using SPSS version 17. Descriptive statistics and Chi-square was employed to significant differences between among fish species, sex, age, length and weight.

Pearson's correlation test was also employed to assess the association between the different variables of age, length and weight in relation to the occurrence of internal parasites. In all the analyses, confidence level was at $95 \%$ and $p<0.05$ was set for significance.

\section{Results}

Out of the 412 sampled fish, 197 (47.8\%) were found infested with internal parasites. Prevalence of $50.22 \%, 91.7 \%$ and $15.6 \%$, were recorded from Oreochromis niloticus, Clarias gariepinus and Cyprinus carpio species, respectively, and the difference between species were found statistically significant at $\mathrm{p}<0.05$ (Table 1 ). As indicated in Table 1 females had higher prevalence of helminthes infection (48.31\%) than their male counterparts (47.4\%), but the difference between sexes was not statistically significant body at $\mathrm{P}>0.05$. The prevalence of internal parasites was also evaluated based on different body length and weight (age) categories. Hence, prevalence of 51.97\%, 46.9\%, 4.6\% and 57.53\% were recorded from $8-12 \mathrm{~cm}, 13-17 \mathrm{~cm}, 18-24 \mathrm{~cm}$ and $\geq 25 \mathrm{~cm}$ length categories, respectively and the difference was found statistically significant at $\mathrm{P}<0.05$. Similarly, prevalence of $45.36 \%, 59.72 \%, 32.78 \%$ and $54.11 \%$ were observed from fingerlings (70-100 g), juvenile (110$200 \mathrm{~g}$ ), young (210-300 g ) and adult ( $\geq 300 \mathrm{~g}$ ), respectively. Likewise the difference between weight categories were also found statistically significant at $\mathrm{P}<0.05$ ( Table 1 ).

In this study, six parasites namely Contracecum spp. (nematoda), Clinostomum spp. (trematoda), Camallanus spp. (nematoda), Eustrongylides spp. (nematoda), Ligula intestinalis (cestoda) and Proteocephalus spp. (cestoda) belonging to different taxonomic groups were recovered from 197 positive sampled fish.

The frequency distribution of internal parasites among the three fish species (Oreochromis, Clarias and Cyprinus spp.) is presented in Table 2. Contracecum (42.6\%) were the most frequently found parasite followed by Clinostomum (38.6\%), Camallanus (7.8\%), Ligula intestinalis (5.2\%), Proteocephalus (3.1\%) and Eustrongylides (2.7\%), from different sites of the fish body. The highest number of parasites were recovered from Oreochromis niloticus 324 (61.95\%), Clarias gariepinus 172 (32.9\%), and Cyprinus carpio 27 (5.15\%) as shown in Table 1.

The frequency distribution of each parasite with respect to the studied fish species has shown that Contracecum was recovered with prevalence rate of 47 (20.9\%), $56(77.8 \%)$, and $0(0 \%)$ from Oreochromis niloticus, Clarias gariepinus and Cyprinus carpio, respectively; Clinostomum 76 (33.8\%) and Eustrongylides 6 (2.7\%) was found only from Oreochromis niloticus; Ligula intestinalis 18 (15.7\%) was found only from Cyprinus carpio. Camallanus 19 (26.4\%) and Proteocephalus $10(13.9 \%)$ were recovered only from Clarias gariepinus as shown in Table 2.

\section{Discussion}

In this study, an overall prevalence rate of $47.8 \%$ was recorded in Oreochromis niloticus, Clarias gariepinus and Cyprinus carpio species. It was observed that significant difference at $p<0.05$ was noted in the prevalence of internal parasites among the studied fish species. The prevalence was higher in Clarias species followed by Oreochromis species and Cyprinus carpio. Our prevalence finding is in agreement 
Citation: Amare A, Alemayehu A, Aylate A (2014) Prevalence of Internal Parasitic Helminthes Infected Oreochromis niloticus (Nile Tilapia), Clarias gariepinus (African Catfish) and Cyprinus carpio (Common Carp) in Lake Lugo (Hayke), Northeast Ethiopia. J Aquac Res Development 5: 233 doi:10.4172/2155-9546.1000233

Page 3 of 5

\begin{tabular}{|c|c|c|c|c|c|}
\hline Risk factors & & No. of fishes examined & No. of fish with parasites (\%) & Parasites Burden (\%) & $X^{2}(P$-value $)$ \\
\hline \multirow[t]{3}{*}{ Species } & Oreochromis niloticus & 225 & $113(50.22)$ & $324(61.95 \%)$ & $\begin{array}{c}103.686 \\
(0.000)\end{array}$ \\
\hline & Clarias gariepinus & 72 & $66(91.7)$ & $172(32.9 \%)$ & \\
\hline & Cyprinus carpio & 115 & $18(15.6)$ & $27(5.15 \%)$ & \\
\hline Total & & 412 & $197(47.8)$ & $523(100 \%)$ & \\
\hline \multirow[t]{2}{*}{ Sex } & Female & 178 & $86(48.31)$ & $350(66.92 \%)$ & $\begin{array}{c}0.031 \\
(0.860)\end{array}$ \\
\hline & Male & 234 & $111(47.44)$ & $173(33.08 \%)$ & \\
\hline Total & & 412 & $197(47.8)$ & $523(100 \%)$ & \\
\hline \multirow[t]{4}{*}{ Length } & $8-12 \mathrm{~cm}$ & 127 & $66(51.97)$ & $194(37.1 \%)$ & $\begin{array}{l}38.546 \\
(0.000)\end{array}$ \\
\hline & $13-17 \mathrm{~cm}$ & 96 & $45(46.9)$ & $121(23.13 \%)$ & \\
\hline & $18-24 \mathrm{~cm}$ & 43 & $2(4.6)$ & $9(1.73 \%)$ & \\
\hline & $\geq 25 \mathrm{~cm}$ & 146 & $84(57.53)$ & $199(38.04 \%)$ & \\
\hline Total & & 412 & $197(47.8)$ & $523(100 \%)$ & \\
\hline \multirow[t]{4}{*}{ Weight (age) } & 70-100 gm (fingerlings) & 194 & $88(45.36)$ & $240(45.9 \%)$ & $\begin{array}{l}11.434 \\
(0.010)\end{array}$ \\
\hline & 110-200 gm (juvenile) & 72 & $43(59.72)$ & $125(23.9 \%)$ & \\
\hline & 210-300 gm (young) & 61 & $20(32.78)$ & $54(10.3 \%)$ & \\
\hline & $\geq 300$ gm (adult) & 85 & $46(54.11)$ & $104(19.9 \%)$ & \\
\hline Total & & 412 & $197(47.8)$ & $523(100 \%)$ & \\
\hline
\end{tabular}

Table 1: Prevalence of internal parasitic helminthes in relation to species, sex, length and weight (ages) of fish in Lake Lugo (Hayke).

\begin{tabular}{|c|c|c|c|c|c|c|c|}
\hline \multirow[t]{2}{*}{ Parasite species } & \multirow[t]{2}{*}{ Taxonomic group } & \multicolumn{3}{|c|}{ Number of fish infested (\%) } & \multirow{2}{*}{$\begin{array}{l}\text { Total parasites } \\
\text { distribution (\%) }\end{array}$} & \multirow{2}{*}{$\begin{array}{l}\text { Parasites burden } \\
(\%)\end{array}$} & \multirow[t]{2}{*}{$X^{2}$ (P-value) } \\
\hline & & Oreochromis iloticus & Clarias ariepinus & Cyprinus carpio & & & \\
\hline Contracecum & Nematoda & $\begin{array}{l}47 \\
(20.9 \%)\end{array}$ & $\begin{array}{l}56 \\
(77.8 \%)\end{array}$ & $\begin{array}{l}0 \\
(0 \%)\end{array}$ & $\begin{array}{l}103 \\
(44.4 \%)\end{array}$ & $\begin{array}{l}223 \\
(42.6 \%)\end{array}$ & $\begin{array}{l}147.324 \\
(0.000)\end{array}$ \\
\hline Clinostomum & Trematoda & $\begin{array}{l}76 \\
(33.8 \%)\end{array}$ & $\begin{array}{l}0 \\
(0 \%)\end{array}$ & $\begin{array}{l}0 \\
(0 \%)\end{array}$ & $\begin{array}{l}76 \\
(32.75 \%)\end{array}$ & $\begin{array}{l}202 \\
(38.6 \%)\end{array}$ & $\begin{array}{l}77.452 \\
(0.000)\end{array}$ \\
\hline Camallanus & Nematoda & $\begin{array}{l}0 \\
(0 \%)\end{array}$ & $\begin{array}{l}19 \\
(26.4)\end{array}$ & $\begin{array}{l}0 \\
(0 \%)\end{array}$ & $\begin{array}{l}19 \\
(8.18 \%)\end{array}$ & $\begin{array}{l}41 \\
(7.8 \%)\end{array}$ & $\begin{array}{l}94.060 \\
(0.000)\end{array}$ \\
\hline Eustrongylides & Nematoda & $\begin{array}{l}6 \\
(2.7 \%)\end{array}$ & $\begin{array}{l}0 \\
(0 \%)\end{array}$ & $\begin{array}{l}0 \\
(0 \%)\end{array}$ & $\begin{array}{l}6 \\
(2.6 \%)\end{array}$ & $\begin{array}{l}14 \\
(2.7 \%)\end{array}$ & $\begin{array}{l}5.060 \\
(0.08)\end{array}$ \\
\hline Ligula intestinalis & Cestoda & $\begin{array}{l}0 \\
(0 \%)\end{array}$ & $\begin{array}{l}0 \\
(0 \%)\end{array}$ & $\begin{array}{l}18 \\
(15.7 \%)\end{array}$ & $\begin{array}{l}18 \\
(7.75 \%)\end{array}$ & $\begin{array}{l}27 \\
(5.2 \%)\end{array}$ & $\begin{array}{l}48.611 \\
(0.000)\end{array}$ \\
\hline Proteocephalus & Cestoda & $\begin{array}{l}0 \\
(0 \%)\end{array}$ & $\begin{array}{l}10 \\
(13.9 \%)\end{array}$ & $\begin{array}{l}0 \\
(0 \%)\end{array}$ & $\begin{array}{l}10 \\
(4.3 \%)\end{array}$ & $\begin{array}{l}16 \\
(3.1 \%)\end{array}$ & $\begin{array}{l}48.397 \\
(0.000)\end{array}$ \\
\hline Total & & $129(55.6 \%)$ & $85(36.6 \%)$ & $18(7.8 \%)$ & $232(100 \%)$ & $523(100 \%)$ & \\
\hline
\end{tabular}

Table 2: Frequency distribution of internal parasites of Oreochromis, Clarias and Cyprinus species at Lugo Lake.

with the reports of Imam and Dewu, [19] and Bichi and Ibrahim [20] that assessed prevalence rate of $47.6 \%$ and $43.4 \%$ in Clarias and Tilapia species, respectively. The findings of this research are higher than Akinsanya et al. [21] who found prevalence rate of $38.7 \%$ in clarias spp.

The higher prevalence of internal helminth parasites in the present study was ascribed to different factors which include absence of proper waste disposal and management system in which the fishes were processed and the waste (scraps and gastrointestinal contents) was dumped in to the Lake Shoreline, traditional ways of fishing which damaged the phytoplankton or zooplankton of the Lake (feed/weed) that enhanced competition for feed and the use of small sized fish nets which trapped the fingerlings and juveniles and environmental pollutions (climate change) and stress caused from the surrounding loges (hotels) and villagers (farmers) of the lake. However, the overall prevalence of internal parasites in the present study was lower compared to the findings of Olofintoye [22] who reported $60.23 \%$ prevalence of parasite; suggesting that the distribution of parasites can be varied from one habitat to the other due to host parasite relationship; abiotic factors like dissolved oxygen, temperature and $\mathrm{pH}$.

Edema et al. [23] reported that some of the factors that enhance parasitic infection in fishes include reduced oxygen content of water, increase in organic matter in the water, and poor environmental conditions. The difference between sexes was not statistically significant, but the prevalence was a bit higher in females $(48.31 \%)$ than males (47.4\%). This observation correspond to the findings of Imam and Dewu [19], Bichi and Ibrahim [20] and Mhaisen et al. [24], that stated female fishes were generally more liable than males to infestations with cestodes, nematodes and trematodes. This could be due to the difference of their physiological condition of the females especially gravids ones [25] which could have had reduced resistance to infection by the parasites [26]. But, it contradicts with the findings of Akinsanya et al. [21] and Allumma and Idowu [12] regarding to sex who found that male specimens presented a higher rate of internal parasite infestation.

The prevalence of internal parasites was also evaluated based on different length and weight (age) categories. This study revealed a higher parasite infestation in the shortest or small $(8-12 \mathrm{~cm})$ and longest or big $(\geq 25 \mathrm{~cm})$ size classes, and in the juvenile $(110-200 \mathrm{~g})$ and adult $(\geq 30$ $0 \mathrm{~g}$ ). This finding was almost in agreement with the reports of Allumma and Idowu [12] and, Bichi and Ibrahim [20] who stated that larger 
Citation: Amare A, Alemayehu A, Aylate A (2014) Prevalence of Internal Parasitic Helminthes Infected Oreochromis niloticus (Nile Tilapia), Clarias gariepinus (African Catfish) and Cyprinus carpio (Common Carp) in Lake Lugo (Hayke), Northeast Ethiopia. J Aquac Res Development 5: 233 doi:10.4172/2155-9546.1000233

Page 4 of 5

fishes were heavily parasitized than the smaller ones. The intensity and prevalence of parasites infection increased with increasing length, size and age of the fish host. Age and sex were shown to influence the degree of parasite infection [25]. The reason for the higher infection rate in adult and young may be because of the longer duration of time the older fish were exposed to the agents in the environment. This increases their chances of acquiring the parasite infection with time. Similar observation of infection being higher in adult was reported by Roberts [27] who noted that longer fish provide greater surface for infection than smaller fish. Moreover, rationale could be deduced from the fact bigger fishes feed on the smaller ones coupled with their greater body size.

Holden and Reed [26] reported that Clarias is one of the best examples of an omnivore. However, a slight difference was observed as compared to the above mentioned researchers findings in that higher prevalence in smallest sized and juveniles in this study. This may be due to the random selection of the specimens and to probable high level of immunity built up in the fish specimens as explained by Akinsanya et al. [21]. Among the organs that were observed only the gills, the stomach and body (abdominal) cavities were found to be infected but, there were no parasites found in intestine. The distribution of the parasites in the gut of fishes could be due to the physiochemical factors operating in the gut, such as nutritional level, $\mathrm{pH}$, osmotic tension and oxygen tension [12].

In this study, six parasites namely Contracecum (Nematoda), Clinostomum (Trematoda), Camallanus (Nematoda), Eustrongylides (Nematoda), Ligula intestinalis (Cestoda) and Proteocephalus (Cestoda) species belonging to different taxonomic groups were recovered from 197 sampled fishes. A total of 523 parasites were identified using standard parasitological techniques. In this regard Contracecum (42.6\%) were the most frequently found parasite followed by Clinostomum (38.6\%), Camallanus( 7.8\%), Ligula intestinalis ( 5.2\%), Proteocephalus spp. (3.1\%) and Eustrongylides( $2.7 \%)$. The higher prevalence recorded of contracecum was attributed to the fact that this parasite has and infests wide range of final and intermediate hosts such as fish-eating birds (cormorants and pelicans) and larval stages are seen in cyprinds (carp and related species), channel catfish and tilapia [16]. Epidemiological studies pertaining to parasitic infestations of fish in Ethiopia are sporadic and were not well documented. However, Moa [28] reported prevalence rate of $42.5 \%$ Contracecum infestation in Tilapia species in Lake Tana, Bahir Dar, Ethiopia. Ligula intestinalis recovery was also reported by Woinishet [29] with prevalence of $16.5 \%$ in Barbus spp. in Lake Tana, Bahir Dar, Ethiopia.

When compared with researches done in other African countries, Bichi and Ibrahim [20] found prevalence rate of $21.2 \%$ due to Clinostomum spp. in Tilapia spp. in Northern Nigeria. Edema et al. [23] reported that all species of fish are vulnerable to various parasitic infections depending on the species of fish and the type of stream inhabited. The highest number of parasites was recovered from Oreochromis niloticus 61.95\%, Clarias gariepinus 32.9\%, and Cyprinus carpio 5.15\%. The higher prevalence of parasite in Oreochromis and Clarias species may be attributed to random sampling of specimens in which the highest sampled and examined species were Oreochromis $(n=225)$ and the high rate of parasitic infestation in Clarias is due to its habit of eating almost anything (omnivores) [19]. The prevalence of Contracecum (20.9\%) in Oreochromis niloticus (Tilapia) in the present study was lower than that reported by Moa [28] i.e., $42.5 \%$ this could be due to the difference in the physiochemical parameters between the Lake Tana and Lake Lugo. However, higher prevalence due to
Contracecum $77.8 \%$ was recovered from Clarias gariepinus which is associated with the feeding habit of the fish as described by Holden and Reed [26]; but not in Cyprinus carpio. Clinostomum (33.8\%) and Eustrongylides (2.7\%) were found only from Oreochromis niloticus. Ligula intestinalis (15.7\%) was found only from Cyprinus carpio. This finding was in line with the reports of Woinishet [29] who assessed $16.5 \%$ prevalence due to Ligula intestinalis in Barbus spp. regardless of the species difference. Proteocephalus spp. recovery in Clarias spp. was reported by Khalil [30], Van As and Basson [31] and Akinsanya et al. [21]. This was attributed to the omnivore nature of this fish species.

In the present study, the prevalence of nematodes $(53.15 \%)$ was found higher followed by trematodes (38.63\%) and cestodes $(8.22 \%)$. The reason for high prevalence of nematodes infestation may be due to the low host specificity of the adult stages of these parasites which makes them capable of infecting different fish genera and species. It may also be because of the availability of the different host required for the completion of the life cycle of these parasites. These host include the piscivorous carnivorous and man as final hosts and gastropod mollusks and fishes as intermediate hosts [16]. The fish may act as intermediate host in some parasites while in others it is the final host.

Single infestations were the predominant cases; but multiple infestations were also common in this study. Multiple infestations were common due to the fact that the environment supports several parasites species thereby exposing the host to simultaneous infection with many of them. The presence of one parasite and its activity within the host weaken the resistance which makes concurrent infection feasible [12].

In conclusion, the results of the present study in Lake Lugo entailed that the importance of internal parasitic infestation as it affects health, palatability, productivity, market and aesthetic value of fish. The prevalence of internal parasitic infestations was very high and the study determined 6 parasitic species present in fish, which were not previously examined parasitologically in this Lake. Thus, the findings of this study are expected to contribute to future studies to protect and develop the ecological potential of Lake Lugo.

\section{Acknowledgement}

This research was done by the grant fund of Wollo University and authors would like to thank the University for the provision of financial support and laboratory facilities. The authors also are thankful to Professor Terry Gipson (Langston University) and Mr. Assefa Tesema (Wollo University) for their assistance in statistical analysis and for providing laboratory facilities.

\section{References}

1. FAO (2012) Review of the fisheries and aquaculture sector: Ethiopia. FAO corporate document repository.

2. FAO (2003) Fishery country profile. Food and Agriculture Organization of the United Nations. FID/CP/ETH Rev 3.

3. FDRE (Federal Democratic Republic of Ethiopia) (2003) Information on fisheries management in the Federal Democratic Republic of Ethiopia.

4. Noga EJ (2010) Fish Disease: Diagnosis and Treatment. 2nd edn WileyBlackwell Publication, USA.

5. Paperna I (1996) Parasites, Infections and Diseases of fishes in Africa- an update, CIFA Technical Paper No. 31, Rome, FAO, 220

6. Khalil LF, Polling K (1997) Checklist of the Helminth Parasites of African Freshwater Fishes. University of the North Department of Zoology. Republic of South Africa, 184

7. Paperna I (1980) Parasites, infections and diseases of fish in Africa. CIFA Tech Paper No 7 FAO Publication 216

8. Roberts JR, Somerville A (1982) Diseases of Tilapia In: Pullin RS and Lowe McConnell RH edn The Biology and culture of Tilapias. ICLARM Conference Proceedings, 7 Manilla, Philiphines, 247-263. 
Citation: Amare A, Alemayehu A, Aylate A (2014) Prevalence of Internal Parasitic Helminthes Infected Oreochromis niloticus (Nile Tilapia), Clarias gariepinus (African Catfish) and Cyprinus carpio (Common Carp) in Lake Lugo (Hayke), Northeast Ethiopia. J Aquac Res Development 5 : 233 doi:10.4172/2155-9546.1000233

Page 5 of 5

9. Kebede E, Getachew T, Taylor WD, Zinabu GM (1992) Eutrophication of Lake Hayq in the Ethiopian Highlands J Plankton Res 14: 1473-1482.

10. Baxter RM, Golobitsch DL (1970) A note on the limnology of Lake Hayke, Ethiopia. Limnology and Oceanography 15:144-148.

11. Thrusfield M (2005). Sampling In: Veterinary Epidemiology, 3nd edn London: Black Well Science Ltd 179-284.

12. Allumma MI, Idowu RT (2011) Prevalence of Gills helminth of Clarias gariepinus in Baga side of Lake Chad J Appl Sci Environ Manage 15: 47-50

13. http://www.emanrese.ca/eman/ecopols/protocols/

14. Kabata Z(1985) Parasites and Diseases of Fish Cultured in the Tropics. Taylor and Francis Ltd 318.

15. Yamaguti S (1985) Systema helminthes of fish. Vol 1 Digentic Trematodes of the vertebrata part 1 and 2, Interscience publishers, Inc New York.

16. Yanong RPE (2002) Nematode (roundworm) infection in fish 1st edn University of Florida, IFAS Cooperatives Extension 1-10

17. Chandra KJ (2004) Fish Parasitology. Lima Printing Press, Mymensingh 176.

18. Pouder DB, Curtis EW, Yanong RPE (2005) Common freshwater fish parasites pictorial guide. Digenean trematodes (FA112) and nematodes (FA113).

19. Imam TS, Dewu RA (2010) Survey of piscine ecto- and intestinal parasites of clarias species sold at Galadima Road fish market, Kano metyropolis, Nigeria. Bioscience Research Communications. 22: 209-214.

20. Bichi AH, Ibrahim AA (2009) A survey of ecto and intestinal parasites of Tilapia Zilli (Gervias) in Tiga Lake, Kano, and Northern Nigeria. Bayero Journal of Pure and Applied Sciences, 2: 79-82.
21. Akinsanya B, Hassan AA, Adeogun AO (2008) Gastrointestinal helminth parasites of the fish Synodontis Clarias (Siluriformes: Mochokidae) from Lekk lagoon, Lagos, Nigeria. Int J Trop Biol 56: 2021-2026.

22. Olofintoye LK (2006) Parasite fauna in some freshwater fish species in Ekiti State, Nigeria. Pakistan J nutr 5: 359-362.

23. Edema CU, Okaka CE, Oboh IP, Okogub BO (2008) A preliminary study of parasitic infections of some fishes from Okhuo River, Benin City, Nigeria. Int $\mathrm{J}$ Biomedical Health Sciences 4.

24. Mheisen FT, Al- salim NK, Khamees NR (1988) Occurrence of parasites of the freshwater Mugilid fish Liza abu (Heckel) from Basra, Southern Iraq J Fish Biology 32: 525-532.

25. Ugwuzor GN (1987) A survey of helminth parasites of fish in Imo River Nig J fish Hydrobiol 2: 23-30.

26. Holden M, Reed W (1972) West African freshwater fish. Longman Publishers, London 45.

27. Roberts JR (1978) Fish pathology. Billiere Tindal, London 268-275.

28. Moa M (2010) Prevalence of Contracecum spp. in Tilapia in Lake Tana Bahir Dar, Ethiopia. Unpublished DVM thesis, Faculty of Veterinary Medicine, University of Gondar, Ethiopia.

29. Woinishet $D$ (2010) Prevalence of fish tapeworm in Barbus spp. in Lake Tana Bahir Dar, Ethiopia. Unpublished DVM thesis, Faculty of Veterinary Medicine University of Gondar, Ethiopia.

30. Khalil LF (1971) Checklist of the helminth parasites of African freshwater fishes. Tech comm 42 Comm. Inst Helm C.A.B. England, England 80.

31. Van As, JG \& L Basson (1984) Checklist of freshwater fish parasites from Southern Africa. S Afr J Wildl 14: 49-61. 